\title{
Diagnosis and management of tumor-like hypophysitis: A retrospective case series
}

\author{
SONGXUE GUO ${ }^{1,2^{*}}$, CHAOHUI WANG $^{3 *}$, JIANMIN ZHANG $^{1}$, YONG TIAN $^{4}$ and QUN WU ${ }^{1}$ \\ Departments of ${ }^{1}$ Neurosurgery and ${ }^{2}$ Burns, Second Affiliated Hospital, School of Medicine, Zhejiang University, \\ Hangzhou, Zhejiang 310009; ${ }^{3}$ Department of Neurosurgery, Ruian People's Hospital, Wenzhou, Zhejiang 325200; \\ ${ }^{4}$ Department of Neurosurgery, Second Affiliated Hospital, Zhejiang Chinese Medical University, \\ Hangzhou, Zhejiang 310005, P.R. China
}

Received November 20, 2014; Accepted November 3, 2015

DOI: $10.3892 / \mathrm{ol} .2015 .4046$

\begin{abstract}
Tumor-like hypophysitis is an uncommon sellar condition that presents as inflammatory lesions on the structures of the pituitary gland. The diagnosis and management of hypophysitis poses a significant challenge, as its clinical manifestation and appearance in imaging studies are difficult to distinguish from that of pituitary tumors. The present retrospective study summarizes two rare cases of primary granulomatous hypophysitis, two cases of lymphocytic hypophysitis, and three cases in which a pathological diagnosis was not determined due to the use of hormone replacement therapy only. The mean age of the patients studied was $45.71 \pm 22.16$ years, and the patients comprised two males and five females. The clinical signs of hypophysitis included headache, fever, gradual decrease in visual acuity, nausea and vomiting. Enhanced magnetic resonance imaging revealed sellar and pituitary stalk lesions, with iso- or hypodense signals on T1-weighted images. Transsphenoidal surgery was performed in three cases. It was challenging to diagnose hypophysitis due to the lack of any significant specific clinical signs. A transsphenoidal biopsy with fast-frozen pathology is able to diagnose hypophysitis. Glucocorticoid therapy may be a potential treatment for hypophysitis, as complete removal of pituitary masses may disable pituitary function.
\end{abstract}

\section{Introduction}

Hypophysitis is an uncommon sellar condition that presents as inflammatory lesions on structures of the hypophysis, including the pituitary gland and stalk (1-3). Histologically,

Correspondence to: Dr Qun Wu, Department of Neurosurgery, Second Affiliated Hospital, School of Medicine, Zhejiang University, 88 Jiefang Road, Hangzhou, Zhejiang 310009, P.R. China

E-mail: wuqun30639@163.com

*Contributed equally

Key words: hypophysitis, diagnosis, steroid treatment, imaging, transsphenoidal surgery hypophysitis may be classified into four distinct types: Lymphocytic (LYH), granulomatous (GRH), xanthomatous and necrotizing (1). LYH is typically secondary to pregnancy and autoimmune diseases, while GRH may be associated with granulomatous processes (4). A number of recent studies have reported IgG4-related hypophysitis and additional mixed subtypes, including lymphogranulomatous and xanthogranulomatous hypophysitis, may also, more rarely, occur (5-7).

Clinically, the typical manifestation of hypophysitis includes headache, hypopituitarism, nausea, vomiting, diabetes insipidus and potentially visual damage (8). The diagnosis of hypophysitis may be challenging due to its various forms and the influence of concomitant diseases (8). The characteristic features of hypophysitis, which may be observed by magnetic resonance imaging (MRI), are a thickened pituitary stalk and an enlarged pyramidal or round-shaped gland (9). Other potential pathological conditions in the sellar region, including tuberculosis, histiocytosis, fungal infections and germinoma infiltrative neoplasms, must be taken into account during differential diagnosis (10).

The optimal therapeutic course for the treatment of hypophysitis is currently disputed (4). Surgery is an effective method for the removal of masses and to obtain an accurate pathological diagnosis of hypophysitis, while high-dose methylprednisolone therapy is an alternative treatment option that provides hormonal replacement (7).

In the present report, seven cases of hypophysitis are described based on biopsies and imaging results, and the limitations underlying the diagnosis and treatment strategies for hypophysitis are discussed. Written informed consent was obtained for all patients.

\section{Case report}

Patients and diagnoses. Seven cases of hypophysitis, including two male and five female patients, were reviewed at the Department of Neurosurgery, Second Affiliated Hospital (Hangzhou, China) between January 2009 and December 2011. The mean age ( \pm standard deviation) of the patients was $45.71 \pm 22.16$ years. The patients presented with a range of symptoms, including headache, fever, gradual 
Table I. Clinical and endocrinological summary of 7 hypophysitis patients.

\begin{tabular}{|c|c|c|c|c|c|c|c|c|}
\hline \multirow[b]{2}{*}{ Case } & \multirow{2}{*}{$\begin{array}{l}\text { Age, } \\
\text { years }\end{array}$} & \multirow[b]{2}{*}{ Gender } & \multirow{2}{*}{$\begin{array}{l}\text { Chief } \\
\text { complaint }\end{array}$} & \multicolumn{2}{|c|}{ Hormone level } & \multirow[b]{2}{*}{ Etiology } & \multirow[b]{2}{*}{ Treatment } & \multirow{2}{*}{$\begin{array}{l}\text { Pathological } \\
\text { result }\end{array}$} \\
\hline & & & & Increased & Decreased & & & \\
\hline 1 & 66 & $\mathrm{~F}$ & $\begin{array}{l}\text { Headache, } \\
\text { visual damage } \\
\text { (1 month) }\end{array}$ & PRL & h-TSH & Idiopathic & $\begin{array}{l}\text { Transsphenoidal surgery; } \\
\text { postoperative regular-dose } \\
\text { methylprednisolone therapy } \\
\text { (160 mg, daily) }\end{array}$ & $\begin{array}{l}\text { Granulomatous } \\
\text { hypophysitis }\end{array}$ \\
\hline 2 & 72 & M & $\begin{array}{l}\text { Headache, } \\
\text { recurrent fever } \\
\text { ( } 2 \text { months })\end{array}$ & FSH & PRL & Idiopathic & $\begin{array}{l}\text { High-dose } \\
\text { methylprednisolone therapy } \\
\text { (500 mg, daily) }\end{array}$ & NA \\
\hline 3 & 46 & M & $\begin{array}{l}\text { Headache, chill, } \\
\text { nausea, vomiting } \\
\text { (3 days) }\end{array}$ & & $\begin{array}{l}\text { h-TSH, PRL, } \\
\text { LH, PGN, } \\
\text { TES, COR }\end{array}$ & Idiopathic & $\begin{array}{l}\text { High-dose } \\
\text { methylprednisolone therapy } \\
\text { ( } 800,600 \text { or } 400 \mathrm{mg} \text {, daily) }\end{array}$ & NA \\
\hline 4 & 29 & $\mathrm{~F}$ & $\begin{array}{l}\text { Headache } \\
\text { (4 months) }\end{array}$ & & $\begin{array}{l}\text { h-TSH, PRL, } \\
\text { TT4, FT4, } \\
\text { COR (8 am), } \\
\text { ACTH }(8 \mathrm{am})\end{array}$ & Pregnancy & $\begin{array}{l}\text { Transsphenoidal pituitary } \\
\text { biopsy; methylprednisolone } \\
\text { therapy ( } 5 \mathrm{mg} \text {, three times } \\
\text { a day) }\end{array}$ & $\begin{array}{l}\text { Lymphocytic } \\
\text { hypophysitis }\end{array}$ \\
\hline 5 & 42 & $\mathrm{~F}$ & $\begin{array}{l}\text { Visual disorder, } \\
\text { nausea, vomiting } \\
\text { (6 months) }\end{array}$ & & $\begin{array}{l}\text { h-TSH, FT3, } \\
\text { TT4, FT4, } \\
\text { COR (8 am), } \\
\text { ACTH (8 am) }\end{array}$ & Idiopathic & Transsphenoidal surgery & $\begin{array}{l}\text { Lymphocytic } \\
\text { hypophysitis }\end{array}$ \\
\hline 6 & 8 & $\mathrm{~F}$ & $\begin{array}{l}\text { Obesity } \\
(2 \text { years })\end{array}$ & h-TSH & & Idiopathic & $\begin{array}{l}\text { Levothyroxine sodium } \\
\text { therapy }\end{array}$ & NA \\
\hline 7 & 57 & $\mathrm{~F}$ & $\begin{array}{l}\text { Headache, } \\
\text { progressive } \\
\text { visual damage } \\
\text { (4 months) }\end{array}$ & PRL & h-TSH & Idiopathic & $\begin{array}{l}\text { Transsphenoidal surgery; } \\
\text { postoperative regular-dose } \\
\text { methylprednisolone therapy } \\
(160 \mathrm{mg} \text {, daily) }\end{array}$ & $\begin{array}{l}\text { Granulomatous } \\
\text { hypophysitis }\end{array}$ \\
\hline
\end{tabular}

PRL, normal range, 1.9-25.0 mg/ml; h-TSH, normal range, 0.35-4.60 mIU/l; FSH (follicular phase), normal range, 2.8-11.3 IU/l; LH (follicular phase), normal range, 1.1-11.6 IU/l; PGN (follicular phase), normal range, $<3.6 \mathrm{nmol} / \mathrm{l}$; TES, normal range, $<2.7 \mathrm{nmol} / \mathrm{l}$; COR, normal range, 154-638 nmol ( $8 \mathrm{am})$ and 79-388 nmol/1 (4 pm); FT3, normal range, 3.5-6.6 pmol/l; TT4, normal range, 60-165 nmol/1; FT4, normal range, 8.9-20.6 pmol/1; ACTH, normal range, 7.2-63.3 pg/ml. F, female; M, male; h-TSH, human thyroid-stimulating hormone; PRL, prolactin; FSH, follicle-stimulating hormone; LH, luteinizing hormone; PRN, progesterone; TES, testosterone; COR, cortisol; TT4, total thyroxine; FT4, free thyroxine; ACTH, adrenocorticotropic hormone; FT3, free triiodothyronine; NA, not applicable.

decrease of visual acuity, nausea and vomiting. Endocrinological examinations of the patients revealed varying levels of hormone indices, including human thyroid-stimulating hormone (h-TSH) and prolactin (PRL) (Table I).

Sagittal and coronal enhanced MRI scans revealed an enlarged pituitary gland with a pyramidal or round shape (a sellar lesion with iso- or hypodense signal on a T1-weighted image) and a thickened pituitary stalk. Following surgical or hormonal therapy, all cases demonstrated improvements to a varying extent (Fig. 1).

Of the 4 patients that underwent transsphenoidal surgery or biopsy, 3 were diagnosed with lymphocytic hypophysitis, and 1 female patient was histopathologically diagnosed with granulomatous hypophysitis (Fig. 2). Additionally, the morphological characteristics of hypophysitis were markedly different from those of pituitary adenomas or other sellar masses. Typical features of hypophysitis include a thickened pituitary stalk, and diffuse enlargement and enhancement of the pituitary gland on MRI, while other masses exhibit asymmetric enlargement or invasion of the surrounding tissue.
When viewed under a microscope, the hypophysitis tissue exhibited a more tensile structure compared with adenomas, which meant that resection was more difficult (Fig. 3).

Outcome and follow-up. Of the 3 patients that underwent transsphenoidal surgery for the removal of sellar masses, a biopsy to identify hypophysitis with fast-frozen pathology was performed in only 1 case, as the patient's tissues did not demonstrate characteristics of a pituitary adenoma. The remaining patients were administered glucocorticoid therapy and experienced positive outcomes. All patients were followed up for a two year period; pituitary function recovered well in all cases and no recurrences were reported.

\section{Discussion}

Diagnosis. Hypopituitarism occurs in the majority of patients with hypophysitis; therefore, an analysis of levels of pituitary hormones in such patients may be useful for evaluation of the characteristics of hypophysitis, even if there are no obvious 
A
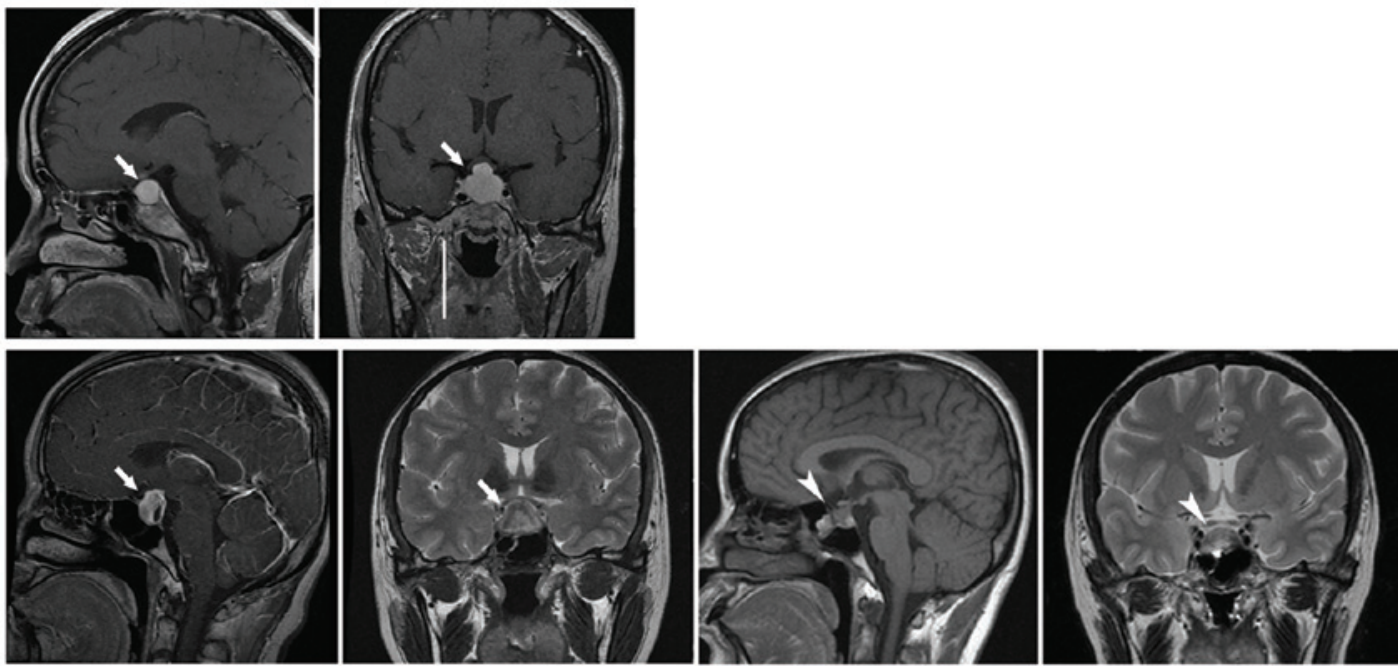

$\mathbf{C}$
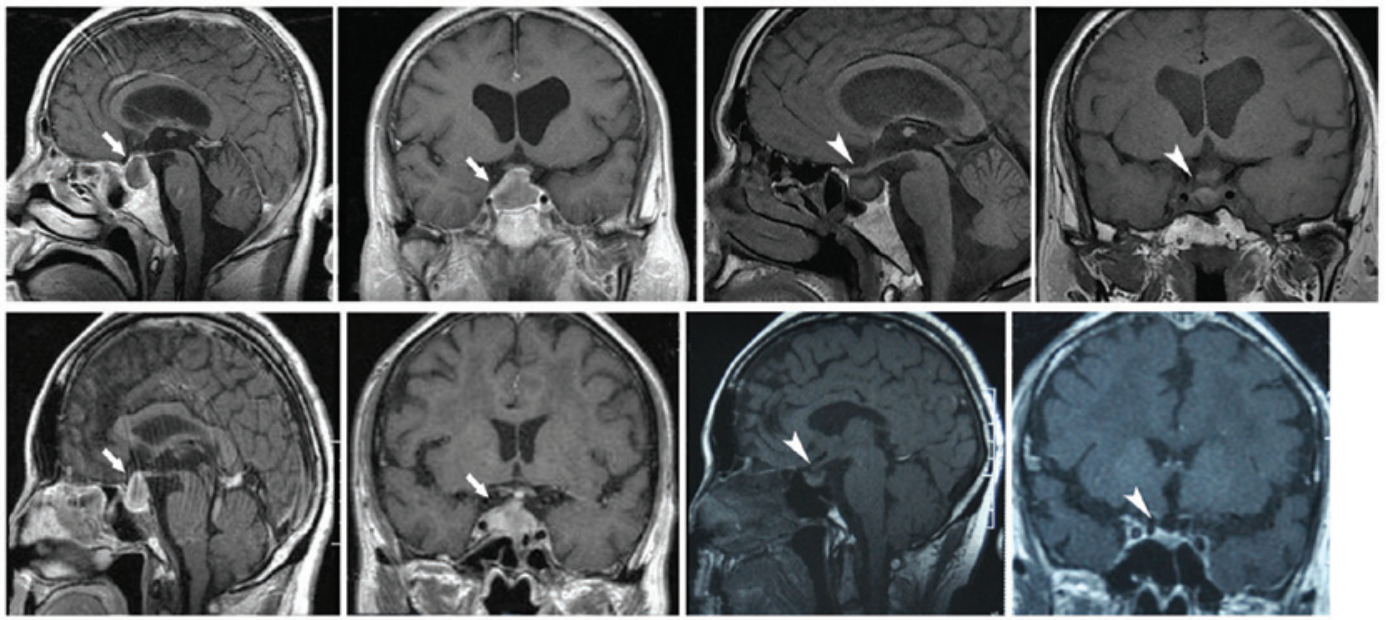

$\mathbf{E}$

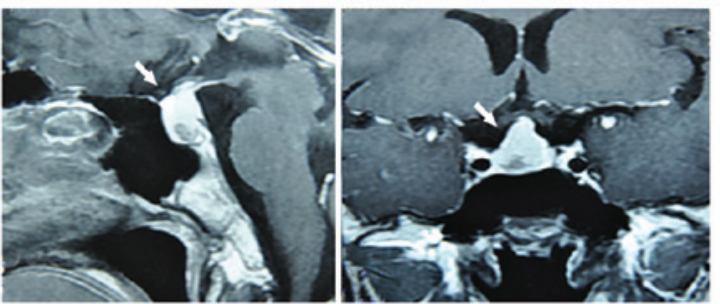

$\mathbf{F}$
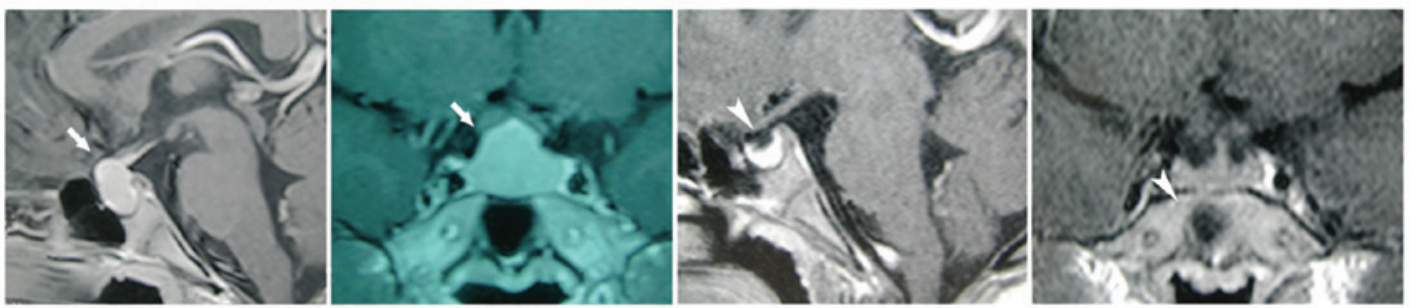

G

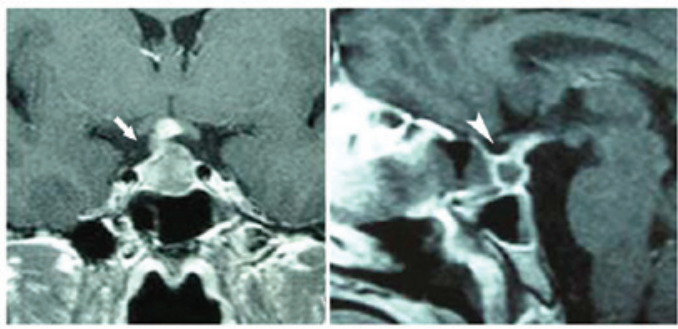

Figure 1. MRI revealed a thickened stalk, and diffuse enlargement and enhancement of the pituitary gland. White tailed arrows indicate the position of the mass, whereas white arrowheads indicate the post-therapeutic condition. (A) Case 1, (left) pre-operative sagittal and (right) coronal MRI images. (B) Case 2, (left) pre-operative and (right) postoperative images showing pituitary gland recovery following high-dose glucocorticoid therapy. (C) Case 3, (left) pre-operative images and (right) postoperative images, showing a reduction in mass size. (D) Case 4, (left) pre-biopsy images and (right) postoperative images following hormone treatment, showing a reduction in mass size. (E) Case 5, pre-operative sagittal and coronal MRI images. (F) Case 6 (left) pretheraputic images and (right) following hormone treatment, showing a reduction in pituitary gland size. (G) Case 7, (left) preoperative image and (right) image showing a contractible mass following therapy. MRI, magnetic resonance imaging. 

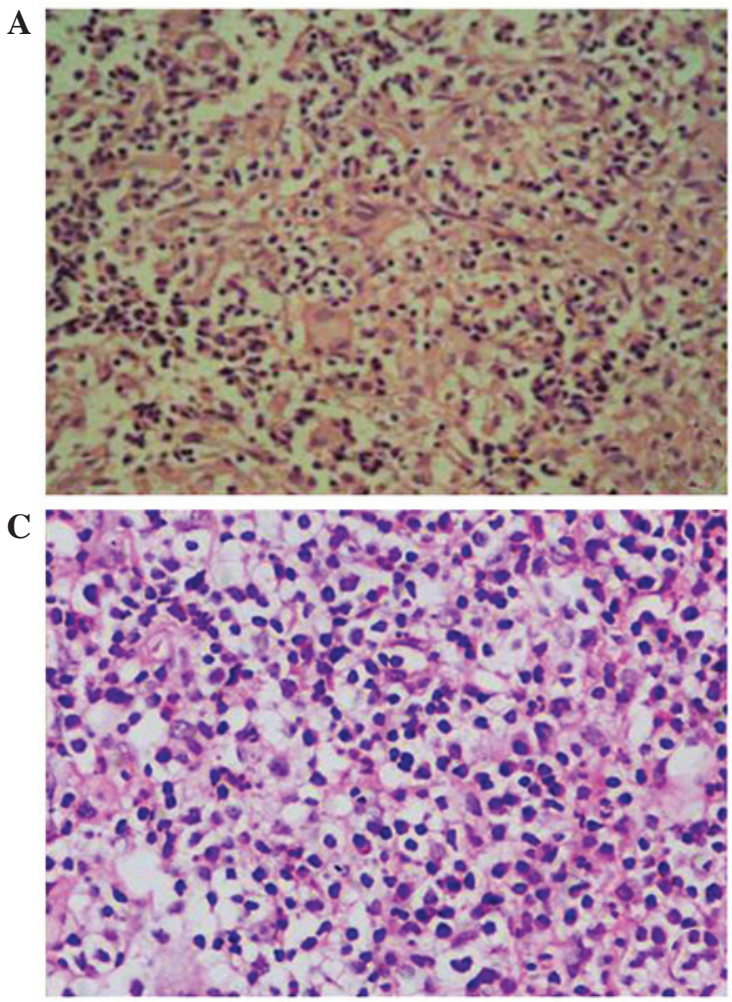

B

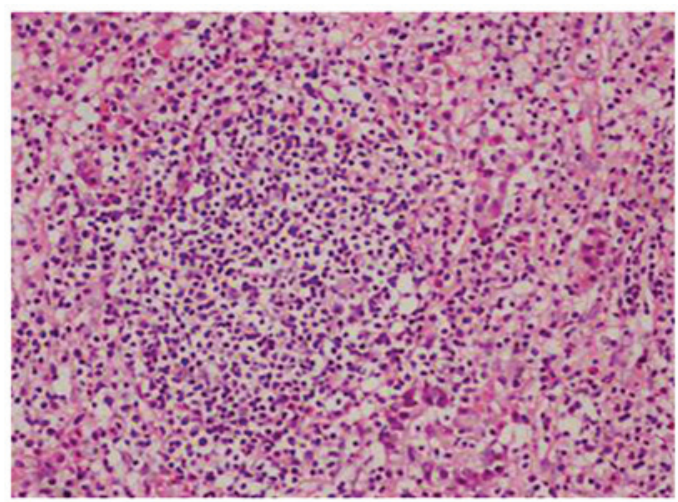

D

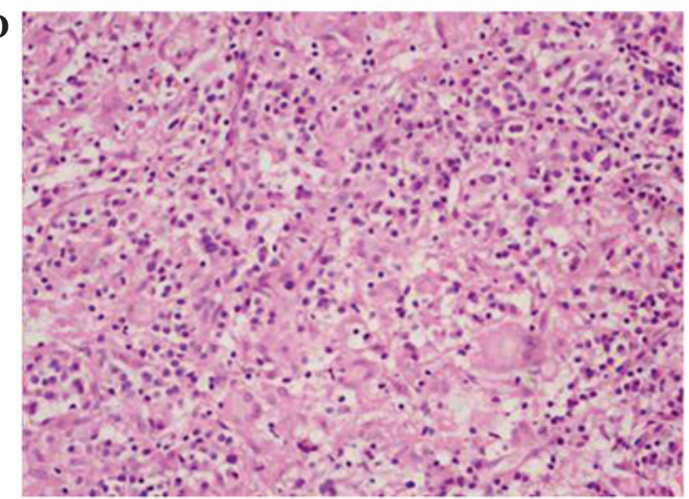

Figure 2. Histological photomicrographs. Hematoxylin and eosin-stained sections taken from the biopsy. (A) Case 1 demonstrates epithelioid cell granuloma with multinucleated giant cells (magnification, $\mathrm{x} 400$ ). (B) Case 4 demonstrates focal replacement of pituitary architecture by a lymphocytic infiltrate (magnification, x800). (C) Case 5 demonstrates focal replacement of pituitary architecture by a lymphocytic infiltrate (magnification, x400). (D) Case 7 demonstrates epithelioid cell granuloma with multinucleated giant cells (magnification, $\mathrm{x} 400$ ).

A

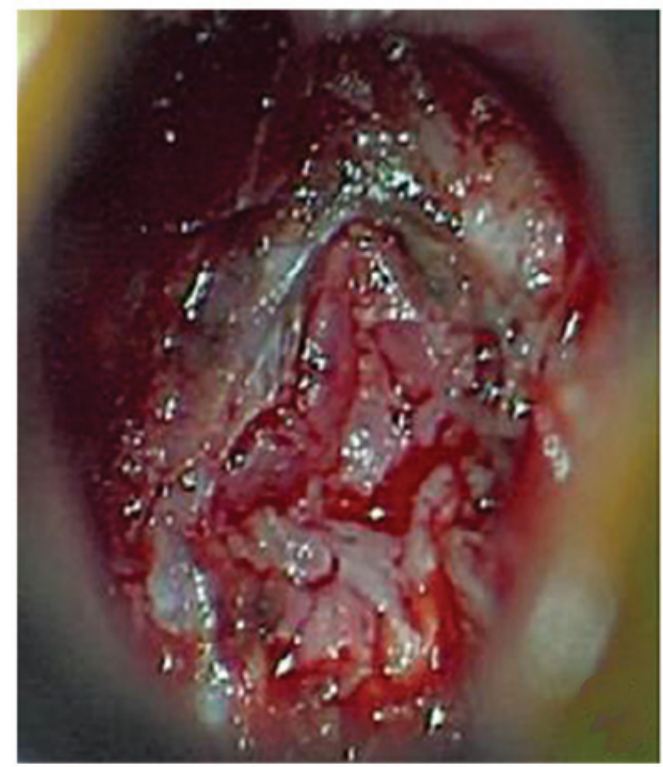

B

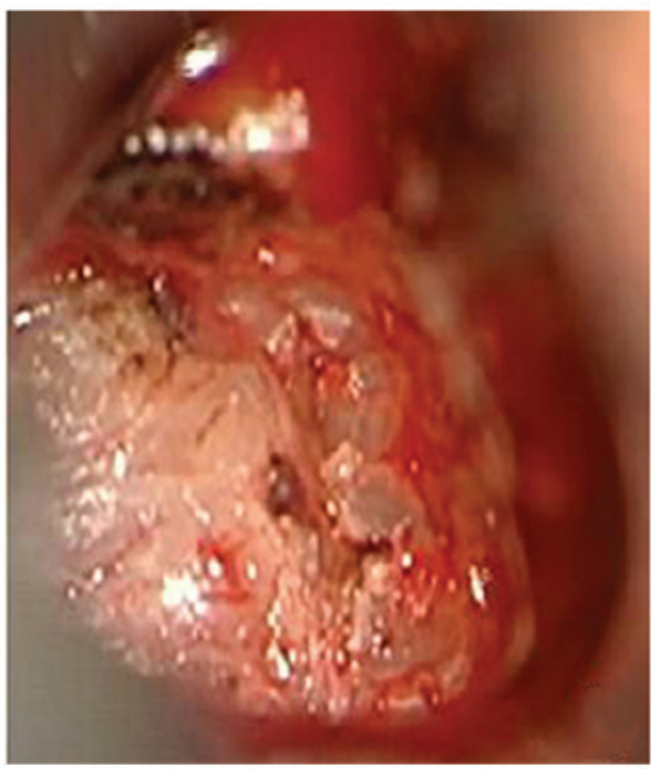

Figure 3. Microscopic images captured during surgery. Images from (A) Case 4 and (B) Case 5 reveal masses caused by hypophysitis.

changes in pituitary hormone levels in certain hypophysitis cases (11). In contrast to the majority of pituitary adenoma patients, hypophysitis patients typically experience a series of marginal changes in the levels of pituitary hormones. It is notable that the majority of the 7 cases investigated in the present study exhibited variations in PRL and h-TSH levels, but no measurable changes in the levels of any other pituitary hormones. Therefore, PRL and h-TSH may be potential indices for presurgical diagnosis. In addition, a number of researchers have identified that appropriate measurements of electrolyte levels and osmolality in the urine and serum are able to assist in identifying the occurrence of diabetes insipidus, a secondary effect of hypophysitis $(12,13)$. The present cases did not demonstrate disequilibrium of electrolytes or 
osmolality in the urine or serum. However, it is possible that the measurement methods utilized were not sensitive enough to diagnose diabetes insipidus. Considering that infectious diseases are the primary cause of hypophysitis, laboratory tests and cultures associated with infectious diseases, particularly tuberculosis and fungal infections, are necessary (14). Although autoimmunity has been proposed as a field that may aid in the diagnosis of hypophysitis, previous studies have identified that anti-pituitary antibodies possess insufficient specificity and sensitivity, negating the potential for measuring autoimmune responses as a laboratory standard in the diagnosis of hypophysitis (15-18).

Pituitary imaging data is able to reveal the characteristic features of hypophysitis. For example, an MRI scan is able to reveal enlargement of the pituitary gland with a pyramidal or round shape, and a thickened pituitary stalk that extends toward the hypothalamus in the suprasellar area (19). An extension of the pituitary gland into the cavernous sinus is observed by imaging in cases of granulomatous hypophysitis (20). Mucosal thickening in the bilateral sphenoid sinus has additionally been reported in certain granulomatous hypophysitis cases, while markedly homogeneous contrast enhancement of the pituitary gland is considered to be a characteristic of lymphocytic hypophysitis (21). Experimental corticosteroid therapy has been discussed as a potential diagnostic tool (2).

Transsphenoidal biopsy has provided the most precise classification of hypophysitis types and allowed for conclusive histopathological diagnoses; however, the biopsy procedure may be traumatic for patients $(7,22)$.

Treatment. In addition to hypopituitarism, diabetes insipidus and other medical issues, a large number of hypophysitis patients present with pituitary masses, visual disorders and severe headaches (14). The cases reviewed in the present study demonstrated these additional characteristic symptoms. Certain previous studies have suggested that resecting the sellar mass as much as possible is a suitable treatment $(7,23,24)$. Furthermore, a fast-frozen pathological diagnosis performed during surgery, and a postoperative histopathological diagnosis, can be undertaken using surgical samples $(22,23)$. Additionally, patients who do not exhibit a strong response to corticosteroid therapy or experience a mass recurrence require standard surgical treatment (22). However, even if surgery is able to sufficiently remove the sellar mass, it is necessary to evaluate potential complications that may arise due to surgery (10). Low doses of radiotherapy have been used on a number of patients exhibiting resistant hypophysitis (25); two patients exhibiting recurrent disease following standard transsphenoidal surgery were treated with low-dose stereotactic radiotherapy. No adverse effects were reported following radiation treatment and mass size was reduced in both cases, while the symptoms were resolved and pituitary function was recovered. A gamma knife has additionally been utilized in certain cases (26). In a patient with histopathologically diagnosed lymphocytic hypophysitis, who underwent transsphenoidal surgery, the disease had proven difficult to resect and following the withdrawal of corticosteroid therapy symptoms returned and mass enlargement was observed. Subsequently, the patient underwent gamma knife treatment, corticoid therapy was stopped and symptoms did not recur (26).
In patients that are unsuitable for surgery due to pregnancy or autoimmune diseases, a high dose of corticosteroid medication may be used to treat hypophysitis (4). Prediagnosis should be based on clinical symptoms, laboratory testing and imaging data to determine the most appropriate medical management for the patient (2). The 3 cases in the present study that were administered high-dose methylprednisolone or levothyroxine sodium therapy demonstrated a positive prognosis. Additionally, the patients that underwent transsphenoidal surgery demonstrated positive outcomes with postoperative regular-dose methylprednisolone therapy. Thus, corticosteroid therapy may be regarded as an effective treatment method for hypophysitis caused by an autoimmune disorder. In addition, pituitary hormone replacement may be used to treat hypophysitis (10). Diabetes insipidus is typically treated effectively with desmopressin (27). Due to the possibility of secondary side effects associated with high-dose glucocorticoid therapy, alternative methods of immune modulation, including azathioprine treatment, have been considered (28).

In conclusion, the most appropriate therapy course for the treatment of hypophysitis remains controversial. Surgical treatment is beneficial for resolving the effects of an enlarged pituitary gland, which may press on the optical or oculomotor nerve, to prevent high intracranial pressure and visual damage (14). However, for patients who are unsuitable for surgery, including those that are pregnant or in poor health, glucocorticoid therapy is the first choice, as total removal of the pituitary masses may functionally disable the pituitary gland (8). In addition, immune modulatory agents may be considered as an alternative therapy to glucocorticoids for recurrent or resistant cases (2). Furthermore, high-dose glucocorticoid therapy may be an effective primary treatment for hypophysitis due to its sensitivity and low rate of traumatic side effects $(10,29)$.

\section{References}

1. Caturegli P, Newschaffer C, Olivi A, et al: Autoimmune hypophysitis. Endocr Rev 26: 599-614, 2005.

2. Carmichael JD: Update on the diagnosis and management of hypophysitis. Curr Opin Endocrinol Diabetes Obes 19: 314-321, 2012.

3. Gutenberg A, Buslei R, Fahlbusch R, Buchfelder M and Bruck W: Immunopathology of primary hypophysitis: Implications for pathogenesis. Am J Surg Pathol 29: 329-338, 2005.

4. Cheung CC, Ezzat S, Smyth HS and Asa SL: The spectrum and significance of primary hypophysitis. J Clin Endocrinol Metab 86: 1048-1053, 2001

5. Landek-Salgado MA, Leporati P, Lupi I, Geis A and Caturegli P: Growth hormone and proopiomelanocortin are targeted by autoantibodies in a patient with biopsyproven IgG4-related hypophysitis. Pituitary 15: 412-419, 2012.

6. Bando H, Iguchi G, Fukuoka H, et al: A diagnostic pitfall in IgG4-related hypophysitis: Infiltration of IgG4-positive cells in the pituitary of granulomatosis with polyangiitis. Pituitary 18: 722-730, 2015.

7. Imber BS, Lee HS, Kunwar S, Blevins LS and Aghi MK: Hypophysitis: A single-center case series. Pituitary 18: 630-641, 2015.

8. Fukuoka H: Hypophysitis. Endocrinol Metab Clin North Am 44: 143-149, 2015.

9. Unlu E, Puyan FO, Bilgi S and Kemal Hamamcioglu M: Granulomatous hypophysitis: Presentation and MRI appearance. J Clin Neurosci 13: 1062-1066, 2006.

10. Laws ER, Vance ML and Jane JA Jr: Hypophysitis. Pituitary 9: 331-333, 2006.

11. Gazioğlu N: Lymphocytic and granulomatous hypophysitis: Experience with nine cases. Neurosurgery 46: 1268, 2000. 
12. Huang CH, Chou KJ, Lee PT, Chen CL, Chung HM and Fang HC: A case of lymphocytic hypophysitis with masked diabetes insipidus unveiled by glucocorticoid replacement. Am J Kidney Dis 45: $197-200,2005$

13. Lupi I, Manetti L, Raffaelli V, Lombardi M, Cosottini M, Iannelli A, Basolo F, Proietti A, Bogazzi F, Caturegli P and Martino E: Diagnosis and treatment of autoimmune hypophysitis: A short review. J Endocrinol Invest 34: e245-252, 2011.

14. Leung GK, Lopes MB, Thorner MO, Vance ML and Laws ER Jr: Primary hypophysitis: A single-center experience in 16 cases. J Neurosurg 101: 262-271, 2004.

15. De Bellis A, Pane E, Bellastella G, Sinisi AA, Colella C, Giordano R, Giavoli C, Lania A, Ambrosio MR, Somma C, et al; Italian Autoimmune Hypophysitis Network Study: Detection of antipituitary and antihypothalamus antibodies to investigate the role of pituitary or hypothalamic autoimmunity in patients with selective idiopathic hypopituitarism. Clin Endocrinol (Oxf) 75: 361-366, 2011.

16. Lupi I, Manetti L, Raffaelli V, Grasso L, Sardella C, Cosottini M, Iannelli A, Gasperi M, Bogazzi F, Caturegli P and Martino E: Pituitary autoimmunity is associated with hypopituitarism in patients with primary empty sella. J Endocrinol Invest 34: e240-e244, 2011

17. Smith CJ, Bensing S, Burns C, Robinson PJ, Kasperlik-Zaluska AA, Scott RJ, Kämpe O and Crock PA: Identification of TPIT and other novel autoantigens in lymphocytic hypophysitis: Immunoscreening of a pituitary cDNA library and development of immunoprecipitation assays. Eur J Endocrinol 166: 391-398, 2012.

18. Leporati P,Landek-Salgado MA,Lupi I, Chiovato L and Caturegli P: IgG4-related hypophysitis: A new addition to the hypophysitis spectrum. J Clin Endocrinol Metab 96: 1971-1980, 2011.

19. Levine SN, Benzel EC, Fowler MR, Shroyer JV $3^{\text {rd }}$ and Mirfakhraee M: Lymphocytic adenohypophysitis: Clinical, radiological, and magnetic resonance imaging characterization. Neurosurgery 22: 937-941, 1988.
20. Vasile M, Marsot-Dupuch K, Kujas M, Brunereau L, Bouchard P, Comoy J and Tubiana JM: Idiopathic granulomatous hypophysitis: Clinical and imaging features. Neuroradiology 39: 7-11, 1997.

21. Goyal M, Kucharczyk W and Keystone E: Granulomatous hypophysitis due to Wegener's granulomatosis. AJNR Am J Neuroradiol 21: 1466-1469, 2000.

22. Shi J, Zhang JM, Wu Q, Chen G, Zhang H and Bo WL: Granulomatous hypophysitis: Two case reports and literature review. J Zhejiang Univ Sci B 10: 552-558, 2009.

23. Honegger J, Fahlbusch R, Bornemann A, Hensen J, Buchfelder M, Müller M and Nomikos P: Lymphocytic and granulomatous hypophysitis: Experience with nine cases. Neurosurgery 40: 713-722; discussion. 722-723, 1997.

24. Buxton N and Robertson I: Lymphocytic and granulocytic hypophysitis: A single centre experience. Br J Neurosurg 15: 242-245; discussion, 245-246, 2001.

25. Selch MT, DeSalles AA, Kelly DF, Frighetto L, Vinters HV, Cabatan-Awang C, Wallace RE and Solberg TD: Stereotactic radiotherapy for the treatment of lymphocytic hypophysitis. Report of two cases. J Neurosurg 99: 591-596, 2003.

26. Ray DK, Yen CP, Vance ML, Laws ER, Lopes B and Sheehan JP: Gamma knife surgery for lymphocytic hypophysitis. J Neurosurg 112: 118-121, 2010.

27. Leroy C, Karrouz W, Douillard C, Do Cao C, Cortet C, Wémeau JL and Vantyghem MC: Diabetes insipidus. Ann Endocrinol (Paris) 74: 496-507, 2013.

28. Lecube A, Francisco G, Rodríguez D, Ortega A, Codina A, Hernández C and Simó R: Lymphocytic hypophysitis successfully treated with azathioprine: First case report. J Neurol Neurosurg Psychiatry 74: 1581-1583, 2003.

29. Khare S, Jagtap VS, Budyal SR, Kasaliwal R, Kakade HR, Bukan A, Sankhe S, Lila AR, Bandgar T, Menon PS and Shah NS: Primary (autoimmune) hypophysitis: A single centre experience. Pituitary 18: 16-22, 2015. 